\title{
Empirical Research on Management Incentives and Corporate Risk-Taking Based on Analysis of A-share Listed Companies
}

\author{
Haihong Li* \\ School of Economics \& Management \\ Beijing University of Chemical Technology \\ Beijing, China \\ lihh@mail.buct.edu.cn
}

\author{
Yufei Wang, Jiting Xu \\ School of Economics \& Management \\ Beijing University of Chemical Technology \\ Beijing, China
}

\begin{abstract}
The global financial crisis that erupted in 2008 has led to an in-depth study of corporate risk-taking issues. This paper selects 2013-2017 China's A-share main board listed company as the research sample and builds an index system to measure the management's salary incentive, shareholding incentive and enterprise risk-taking. Using the STATA, the sample data is analyzed by regression analysis and get following major conclusions: (1) Management salary and shareholding incentives have a facilitating effect on corporate risk-taking and can enhance the level of corporate risk-taking; (2) The promotion effect of management incentives on corporate risk-taking in nonstate-owned enterprises are more effective and more sensitive. Finally, this paper proposes relevant suggestions for improving the management incentive mechanism of listed companies.
\end{abstract}

Keywords-management salary incentives; management shareholding incentives; corporate risk-taking

\section{INTRODUCTION}

The company system enhances operating efficiency and also intensifies the contradiction between management and shareholders because of information asymmetry. In recent years, the topic of "high-salary" of managers has been heatedly debated, and the psychological gap between employees and managers is huge, which is likely to cause firm confusion.

Based on above research background, this paper divides the management compensation incentives into monetary salary incentives and shareholding incentives. It mainly studies the impacts of the two incentives on the risk-taking of corporations and further explores its internal mechanism and specific relationship.

\section{LITERATURE REVIEW}

Foreign researches on corporate risk-taking issues were earlier than domestic study. The majority of scholars focus on the level of bank risk-taking, and the research on the level of corporate risk-taking arise in recent years. Haq, Pathan and Williams (2010) selected banks as research objects, the research shows that management compensation incentives and bank risk exposures will change over time. The drawn graph is a U-shaped graph[1]. Li Yingchun (2012) studied the impact of corporate surplus compensation on corporate risk-taking. The empirical analysis found that the two are positively correlated, and very significant, state-owned enterprises(SOEs) are more prominent than non-SOEs [2]. Boubakri et al. (2013) study showing that as the proportion of foreign ownership increased, the level of risk-taking is also increasing[3]. Wang Dong and $\mathrm{Wu}$ Desheng (2016) found the management equity incentives will promote the improvement of the risk-taking level, and the effect in SOEs is not significant as private enterprises[4]. Ye Hongyu and Wen Xinyu (2018) found that CEO equity incentives promoted risk-taking[5].

It can be seen that monetary compensation incentives and shareholding incentives can improve the level of corporate risk-taking has been proved by most scholars. Based on the above analysis, this paper believes that monetary incentives can encourage executives to bear higher risks. In summary, the first hypothesis $\mathrm{H} 1$ of this paper is proposed:

H1a: Management monetary incentives have a positive effect on corporate risk-taking

H1b: Management shareholding incentives can increase the level of risk-taking.

At present, China is in the period of supply-side reform. This requires enterprises to attach importance to risk-taking and cannot arbitrarily bear the risk of not matching the company's capabilities. Chen Zhen and Ling Yun (2013) found that compared with private enterprises, senior managers of SOEs are more concerned about their political relations, national political and economic policies, and do not care much about their wealth[6]. Zhang Honghui, Zhang Linyi (2016) found that for senior executives of SOEs, the promotion of positions did not stimulate executives and could not improve the level of risk-taking [7]. Zhu Xiaolin and Fang Yongjun (2017) found that the incentive effect of the executive team's salary gap is not significant in SOEs, and only exists in private enterprises[8]

It can be seen from the above literature that the effect of management incentives on the level of risk-taking is more obvious in private enterprises. Based on the above analysis, we present the second hypothesis $\mathrm{H} 2$ of this paper: 
H2a: The promotion effect of management monetary incentives on corporate risk-taking is more effective and sensitive in non-SOEs.

H2b: Management shareholding incentives can increase risk-taking, and the positive relation of the two will be higher in non-SOEs.

\section{EMPIRICAL STUDY DESIGN AND SELECTION OF INDICATORS}

Because of sample selection of previous literature usually limited in a specific industry, this paper selects 2013-2017 Shanghai-Shenzhen A-share mainboard 5035 listed companies as research samples. More samples than other researches will get results of analysis more meaningful.

In view of the imperfect capital market in China, the stock price is greatly affected by external factors. This paper uses the fluctuation value of the return on assets as the proxy variable of risk-taking. The specific calculation method refers to the practice of Faccio et al. [9] (2011), and uses three years as the observation value to calculate the risk exposure of the enterprise. The specific calculation formula is as follows:

$$
\begin{aligned}
& \text { Risk }=\sqrt{\frac{1}{T-1} \sum_{t=1}^{T}\left(\operatorname{AdjROA}_{i, t}-\frac{1}{T} \sum_{t=1}^{T} \operatorname{AdjROA}_{i, t}\right)} \\
& \operatorname{AdjROA}_{i, t}=\operatorname{ROA}_{i, t}-\frac{1}{N} \sum_{k=1}^{N} R O A_{i, t}
\end{aligned}
$$

$\mathrm{i}$ in formulas (1) and (2) represents a company in the sample, $\mathrm{N}$ is all sample companies, $\mathrm{k}$ refers to the kth of the 15035 sample companies, $\mathrm{t}$ is a year in three years, $\mathrm{T}$ refers to the length of time rolling 3 .

In this paper, the management incentive is set as the explanatory variable, combined with the actual situation of the incentive of China's enterprises; we take the monetary incentive and shareholding incentive as the proxy variable of manager's incentive. The specific calculation method refers to Gao Lei (2018)[10] (see Table I for details). The control variables select the size of the company (Size), the assetliability ratio (Lev), the growth (Growth), the nature of ownership (State), the age of the enterprise (AGE) and the proportion of the largest shareholder (Top1). As shown in TABLE I.

\begin{tabular}{|c|c|}
\hline Variable symbol & Description \\
\hline RISK & Volatility of the standard deviation of ROA in the last three years \\
\hline PAY & Top three executives' compensation to total compensation \\
\hline MR Size Lev Age Growth Top1 State Ind Year & $\begin{array}{c}\text { management shares to total assets } \\
\text { Size, ln (assets) } \\
\text { Liability to assets } \\
\text { Ln(Listed company operating period) } \\
\text { The difference between the business income of the current year and previous year to the } \\
\text { total operating income of the previous year } \\
\text { Number of shares held by the largest shareholder / total number of shares } \\
\text { SOEs are 1, and non-SOEs are } 0 \\
\text { Industry dummy variable } \\
\text { Year dummy variable }\end{array}$ \\
\hline
\end{tabular}

TABLE I. DESCRIPTION OF VARIABLES ADOPTED

The research object of this paper is the impact of management incentives on enterprise risk-taking. Firstly, do studies on the relationship based on the whole sample and the sub-sample. Secondly, according to the different nature of ownerships, study how the management incentives affect the risk-taking. Take previous studies for reference, this paper establishes the following model:

RISK $=\partial_{0}+\partial_{1}$ PAY $+\partial_{2}$ Size $+\partial_{3}$ Lev $+\partial_{4}$ AGE $+\partial_{5}$ Growth $+\partial_{6}$ TOP 1

$+\partial_{7}$ State $+\Sigma$ Year $+\Sigma \operatorname{Ind}+\varepsilon$

RISK $=\partial_{0}+\partial_{1} \mathrm{MR}+\partial_{2}$ Size $+\partial_{3} \mathrm{Lev}+\partial_{4}$ AGE $+\partial_{5}$ Growth $+\partial_{6}$ TOP $1+$ $\partial_{7}$ State $+\Sigma$ Year $+\Sigma \operatorname{Ind}+\varepsilon$

The dependent variables of model (3)(4) are enterprise risktaking (RISK), and the explanatory variables are management monetary salary incentive (PAY) and shareholding incentive (MR). According to the theoretical analysis above, we estimate management salary incentives and shareholding incentives can promote the improvement of the risk-taking level of enterprises, that is, H1a and H1b are assumed to be established.
RISK $=\partial_{0}+\partial_{1} \mathrm{PAY}+\partial_{2}$ State $* \mathrm{PAY}+\partial_{3}$ Size $+\partial_{4}$ Lev $+\partial_{5}$ AGE

$+\partial_{6}$ Growth $+\partial_{7}$ TOP $1+\partial_{8}$ State $+\Sigma$ Year $+\Sigma$ Ind $+\varepsilon$

$$
\text { RISK }=\partial_{0}+\partial_{1} \text { MR }+\partial_{2} \text { State } * \text { MR }+\partial_{3} \text { Size }+\partial_{4} \text { Lev }+\partial_{5} \text { AGE }
$$

$+\partial_{6}$ Growth $+\partial_{7}$ TOP $1+\partial_{8}$ State $+\Sigma$ Year $+\Sigma$ Ind $+\varepsilon$

In order to test H2, on the basis of model (3), add the interaction item of management salary incentive (PAY) and property (State), ie Model (5); on the basis of model (4), add the shareholding incentive (MR) and the property (State) as model (6); the coefficient of SOEs is determined by $\left(\partial_{1}+\partial_{2}\right)$, and the coefficient of non-SOEs is determined by $\partial_{1}$. 


\section{EMPIRICAL STUDY RESULTS}

\section{A. Descriptive statistics analysis}

TABLE II. PANEL A: DESCRIPTION VALUE OF MAIN VARIABLE

\begin{tabular}{|c|c|c|c|}
\hline Variable & Mean & STDEV & Median \\
\hline RISK & 0.0312 & 0.1741 & 0.0172 \\
\hline PAY & 0.4006 & 0.1240 & 0.3796 \\
\hline MR & 0.0112 & 0.0295 & 0.0005 \\
\hline Growth & 0.2643 & 2.2185 & 0.1204 \\
\hline Roa & 0.0604 & 0.0713 & 0.0538 \\
\hline Size & 22.4305 & 1.2625 & 22.2707 \\
\hline Lev & 0.4469 & 0.2085 & 2.5785 \\
\hline Top1 & 0.3154 & 0.1405 & 0.8411 \\
\hline AGE & 2.2344 & 0.7482 & 3.2958 \\
\hline State & 0.3321 & 0.4710 & 1.0000 \\
\hline
\end{tabular}

Panel B: Description value of 2 groups--SOEs (state=1) (1672 sample

\begin{tabular}{|c|c|c|c|}
\hline Variable & Mean & STDEV & Median \\
\hline RISK & 0.0323 & 0.2954 & 0.0146 \\
\hline PAY & 0.3749 & 0.1132 & 0.3565 \\
\hline MR & 0.0006 & 0.0027 & $1.31 \mathrm{E}-05$ \\
\hline Growth & 0.1405 & 1.7635 & 0.0637 \\
\hline Roa & 0.0516 & 0.0536 & 0.0464 \\
\hline Size & 22.9961 & 1.3746 & 22.8685 \\
\hline Lev & 0.5231 & 0.1963 & 0.5325 \\
\hline Top1 & 0.3489 & 0.1446 & 0.3326 \\
\hline AGE & 2.6720 & 0.4556 & 2.8332 \\
\hline
\end{tabular}

Panel B: Description value of 2 groups--SOEs (state=0) (3363 sample

\begin{tabular}{|c|c|c|c|}
\hline \multicolumn{5}{|c|}{ firms) } \\
\hline Variable & Mean & STDEV & Median \\
\hline RISK & 0.0307 & 0.0451 & 0.0184 \\
\hline PAY & 0.4134 & 0.1271 & 0.3927 \\
\hline MR & 0.0180 & 0.0346 & 0.0029 \\
\hline Growth & 0.3258 & 2.4109 & 0.1546 \\
\hline Roa & 0.0647 & 0.0783 & 0.0577 \\
\hline Size & 22.1492 & 1.0997 & 22.0562 \\
\hline Lev & 0.4090 & 0.2041 & 0.4007 \\
\hline Top1 & 0.2988 & 0.1353 & 0.2804 \\
\hline AGE & 2.0169 & 0.7698 & 1.9459 \\
\hline
\end{tabular}

Table II is a descriptive statistical result of the main variables and groupings. It can be seen from Panel A that the mean value of RISK is 0.0312 and the median is 0.0172 , which is similar to other authors. It is found through literature that firms in developed countries have higher risk tolerance, the mean value of the United States is around 0.05. Compared with other countries and regions, the level of corporate risk-taking in China is not too high, For PAY (Management Salary Incentive), the standard deviation is 0.124 , which indicates that the executive pay of different enterprises in China is quite different. The mean value of MR 0.0122 reflects that the management shareholding of listed companies in China is far lower than the average level of western developed countries. The minimum 0 and median 0.0005 reflect that there are only a few listed companies in China that use management equity incentives, and the incentives in these companies that implement equity incentives are not high.

Panel B reported the group description statistics based on the ownership of the main variables. It can be seen that the average value of risk-taking of SOEs is 0.0323, the standard deviation is 0.2954 , and the median is 0.1462 . As for nonSOEs, the figures are 0.0307, 0.0451, and 0.0184. By comparison, it can be seen that the risk-taking level of SOEs is higher than that of non-SOEs. The reason may be that nonSOEs are not willing to bear too high risks. The average value of PAY for SOEs and non-SOEs is 0.3749 and 0.4134 respectively, and the median is 0.3565 and 0.3927 respectively. Non-SOEs are slightly higher than SOEs, and the difference is not too large.

\section{B. Regression analysis}

TABLE III. MANAGEMENT SALARY INCENTIVES AND CORPORATE RISKTAKING

\begin{tabular}{|c|c|c|c|}
\hline & Estimate & T & P \\
\hline PAY & 0.01444 & 4.79 & 0 \\
\hline Growth & 0.00047 & 0.33 & 0.739 \\
\hline Size & -0.0048 & -12.02 & 0 \\
\hline Lev & 0.00643 & 2.81 & 0.005 \\
\hline Top1 & 0.00191 & 0.75 & 0.452 \\
\hline AGE & 0.00352 & 5.58 & 0 \\
\hline State & -0.00255 & -3.36 & 0.001 \\
\hline Cons & 0.11715 & 13.95 & 0 \\
\hline Year \& Ind & & Control & \\
\hline $\mathrm{N}$ & & 5035 & \\
\hline $\mathrm{R}$ & & 0.0902 & \\
\hline
\end{tabular}

TABLE IV. MANAGEMENT SHAREHOLDING INCENTIVES AND CORPORATE RISK EXPOSURE

\begin{tabular}{|c|c|c|c|}
\hline & Estimate & T & P \\
\hline MR & 0.07058 & 3.19 & 0.001 \\
\hline Growth & 0.00056 & 0.4 & 0.687 \\
\hline Size & -0.00495 & -12.37 & 0 \\
\hline Lev & 0.00681 & 2.96 & 0.003 \\
\hline Top1 & 0.00364 & 1.46 & 0.143 \\
\hline AGE & 0.00433 & 6.58 & 0 \\
\hline State & -0.00264 & -3.51 & 0 \\
\hline Cons & 0.12313 & 14.71 & \\
\hline Year \& Ind & & Control & \\
\hline $\mathrm{N}$ & & 5035 & \\
\hline $\mathrm{R}$ & & 0.0883 & \\
\hline
\end{tabular}

From Table III, Table IV, we can get: The company's salary incentive mechanism and the size of the company, the assetliability ratio and the nature of property rights are all important factors affecting the company's risk-taking level. The empirical 
test results for Model 3 show that the regression coefficient of the variable of management salary incentive is 0.01444 , and reaches $1 \%$ significance level, indicating that the management salary incentive has a positive correlation with the enterprise risk-taking, thus verifying H1a. The test of Model 4 shows that the regression coefficient of the variable of management shareholding incentive is 0.07058 with a significant positive correlation at the $1 \%$ level, thus verifying $\mathrm{H} 1 \mathrm{~b}$.

TABLE V. MANAGEMENT INCENTIVES, PROPERTY HETEROGENEITY AND CORPORATE RISK-TAKING-MODEL5

\begin{tabular}{|c|c|c|c|}
\hline \multirow{2}{*}{ Pay } & Full sample & State-owned & $\begin{array}{c}\text { Non-state- } \\
\text { owned }\end{array}$ \\
\hline \multirow{2}{*}{ Pay*State } & 0.01978 & 0.01851 & 0.00341 \\
\hline \multirow{2}{*}{ State } & $(5.51)$ & $(4.99)$ & $(0.67)$ \\
\cline { 2 - 4 } & $(-0.01800$ & & \\
\cline { 2 - 4 } & 0.00468 & & \\
\hline \multirow{2}{*}{ Growth } & $(2.17)$ & & -0.00154 \\
\cline { 2 - 4 } & $(-0.00058$ & -0.00032 & $(-0.53)$ \\
\hline \multirow{2}{*}{ Size } & -0.00519 & -0.006111 & -0.00425 \\
\cline { 2 - 4 } & $(-12.6)$ & $(-10.9)$ & $(6.74)$ \\
\hline \multirow{2}{*}{ Lev } & 0.00923 & 0.008671 & 0.012095 \\
\cline { 2 - 4 } & $(3.79)$ & $(2.88)$ & $(2.76)$ \\
\hline \multirow{2}{*}{ Top1 } & 0.00067 & 0.00334 & -0.00163 \\
\cline { 2 - 4 } & $(0.27)$ & $(1.03)$ & $(-0.39)$ \\
\hline \multirow{2}{*}{ AGE } & 0.00364 & 0.004781 & 0.00146 \\
\cline { 2 - 4 } & $(5.76)$ & $(6.16)$ & $(1.23)$ \\
\hline \multirow{2}{*}{ Cons } & 0.12115 & 0.142191 & 0.103515 \\
\cline { 2 - 4 } & $(14.17)$ & $(11.91)$ & $(8.11)$ \\
\hline Year\&Ind & Control & Control & Control \\
\hline N & 5035 & 3363 & 1672 \\
\hline R & 0.0951 & 0.0878 & 0.1476 \\
\hline
\end{tabular}

TABLE VI. MANAGEMENT INCENTIVES, PROPERTY HETEROGENEITY AND CORPORATE RISK-TAKING-MODEL6

\begin{tabular}{|c|c|c|c|}
\hline & Full sample & State-owned & $\begin{array}{c}\text { Non-state- } \\
\text { owned }\end{array}$ \\
\hline \multirow[t]{2}{*}{$\mathrm{Mr}$} & 0.06968 & 0.05903 & 0.64134 \\
\hline & (3.15) & (.63) & $(2.51)$ \\
\hline \multirow{2}{*}{ Mr*state } & 0.51982 & & \\
\hline & $(2.47)$ & & \\
\hline \multirow{2}{*}{ State } & -0.00315 & & \\
\hline & $(-4.06)$ & & \\
\hline \multirow{2}{*}{ Growth } & 0.00042 & -0.00030 & -0.00204 \\
\hline & $(0.3)$ & $(-0.19)$ & $(-0.7)$ \\
\hline \multirow{2}{*}{ Size } & -0.00492 & -0.00632 & -0.00423 \\
\hline & $(-12.29)$ & $(-11.35)$ & $(-6.67)$ \\
\hline \multirow{2}{*}{ Lev } & 0.00698 & 0.00916 & 0.012732 \\
\hline & (3.03) & (3.02) & $(2.96)$ \\
\hline \multirow{2}{*}{ Top1 } & 0.00421 & 0.00559 & 0.00053 \\
\hline & $(1.68)$ & $(1.74)$ & $(0.13)$ \\
\hline \multirow{2}{*}{ Age } & 0.00448 & 0.00564 & 0.002803 \\
\hline & (6.77) & (7.07) & (2.11) \\
\hline \multirow{2}{*}{ Cons } & 0.12209 & 0.15136 & 0.099393 \\
\hline & (14.56) & (12.83) & (7.69) \\
\hline Year\&ind & Control & Control & Control \\
\hline $\mathrm{N}$ & 5035 & 3363 & 1672 \\
\hline $\mathrm{R}$ & 0.0895 & 0.0828 & 0.1526 \\
\hline
\end{tabular}

As shown in Table $\mathrm{V}$, the dependent variable is the enterprise risk-taking level, and the explanatory variables are the management salary incentive and the shareholding incentive. The correlation of SOEs is not significant, and the coefficient of non-SOEs is 0.01851 , which is greater than the coefficient of SOEs, which is 0.00341 . It can be initially confirmed that $\mathrm{H} 2 \mathrm{a}$ is established. In the whole sample regression, $\partial_{1}+\partial_{2}=0.00178, \quad \partial_{1}=0.01978$, both are significant at the level of $1 \%$, but the regression coefficient of non-SOEs is greater than that of SOEs, which is consistent with $\mathrm{H} 2 \mathrm{a}$, that is, the promotion effect of management salary incentives on corporate risk-taking is more effective and sensitive in non-SOEs.

According to the regression results of Model 6, the regression coefficient of SOEs is significant at $10 \%$, and nonSOEs are significant at $1 \%$. From the full sample regression, it can be seen that the degree of correlation of SOEs is not as highly relevant as non-SOEs, so whether they are full or subsamples, the results are consistent with H2b.

\section{CONCLUSION}

This paper studies the interaction between management incentives and corporate risk-taking and further explores the impact of different ownerships on the relationship between management incentives and corporate risk-taking. So far, this paper has drawn the following conclusions:

(1) The management's salary incentives and shareholding incentives have a facilitating effect on corporate risk-taking and can enhance the level of corporate risk-taking.

(2) The promotion effect of management salary incentives and shareholding incentives on corporate risk-taking is more effective and sensitive in non-SOEs.

(3) For SOEs, shareholding incentives can stimulate management more than salary incentives in increasing the desire for risk-taking.

There are some suggestions: First, strengthen management's shareholding incentives, continuously improve the salary compensation incentive system, and improve the compensation incentive mechanism.

Second, design reasonable and efficient performance appraisal indicators to enhance management's willingness to take risks, and promote internal corporate governance.

Third, cultivate the ability of senior managers' risk management. At the same time, the government should increase the intensity of the privatization reform.

\section{REFERENCES}

[1] M. Haq, S. Pathan, B. Williams. Managerial Incentives, Market Power and Risk-taking. SSRN Working papers, No.30, 2010.

[2] L. Yingchun. Residual compensation, investor preferences and corporate risk exposure [J]. Shandong Social Sciences, 2012(07), PP.148-150+134.

[3] N. Boubakri, J.C. Cosset, W. Saffar. The Role of State and Foreign Owners in Corporate Risk-taking: Evidence from Privatization [J]. Journal of Financial Economics, Vol.108, No.3, PP. 641-658, 2013.

[4] W. Dong, W. Desheng. Equity Incentives and Risk-Taking: Evidence from Chinese Listed Companies [J], Nankai Management Review, 2016, 19(03):157-167. 
[5] Y. Hongyu, W. Xinyu. An Empirical Study of the Impact of Management Equity Incentives on Firm Performance: Based on the Mediating Role of Risk-Taking [J]. Journal of Shandong University of Finance and Economics, 2018, 30(03):90-98.

[6] C. Zhen, L. Yun. Enterprise Risk, Property Rights and Executive Compensation - Performance Sensitivity [J]. Economic management, 2013, 35(06):54-61.

[7] Z. Honghui, Z. Linyi. Differences in property rights, promotion incentives and corporate risk-taking [J]. Economic management, 2016 , 38(05):110-121.
[8] Z. Xiaolin, F. Yongjun. CEO power, executive team pay gap and corporate risk [J]. Economic latitude, 2018, 35(01):100-107.

[9] R. Aggarwal, A. Samwick. The Other Side of the Trade-off: The Impact of Risk on Executive Compensation. Journal of Political Economy, No.107, PP65-105, 1999.

[10] G. Lei. Research Status and Development Trend of Enterprise Risk Management [J]. Financial Sector (Academic Edition), 2018(19):53. 